\title{
Kuantum Liderliğin, Yönetim Tarzları ve Örgütsel Bağlılık Bağlamında Analizi ${ }^{1}$
}

\author{
DOI: 10.26466/opus.938653 \\ * \\ Methi Celik* - Şefika Şule Erçetin** \\ * Dr., Şube Müdürü, Milli Eğitim Bakanlığı, Ankara/Türkiye \\ E-Posta: \\ methicelik@gmail.com \\ ORCID: $\quad \underline{0000-0003-3806-4985}$ \\ ** Prof. Dr. Hacettepe Üniversitesi, Eğitim Fakültesi, Ankara/Türkiye \\ E-Posta: sefikasule@gmail.com \\ ORCID: $\quad \underline{0000-0002-7686-4863}$
}

Öz

Bu çalışmada öğretmen görüşlerine göre; okul yöneticilerin kuantum liderlik davranışı sergilemeleri, okul yöneticilerinin yönetim tarzlar ve okullardaki ö̆gretmenlerin örgütsel bağhllklarına ilişkin öğretmenlerin görev yaptıklar okul düzeyi ve cinsiyet değişkenlerine göre değerlendirmeleri analiz edilmiştir. Araştırmada; okul yöneticilerinin kuantum liderlik davranışları ve yönetim tarzları ile öğretmenlerin örgütsel bağhllık düzeyine ilişkin olarak ilişkisel tarama modeli çerçevesinde incelenmiştir. Araştırmanın evreni 2020 - 2021 eğitim öğretim yıllnda Ankara İli merkez ilçelerinde görev yapan 47.233 öğretmen oluşturmuştur. Araştırmanın örneklemi belirlenirken tabakalı örnekleme yöntemi kullanılmıştır. Araştırmada Erçetin, Potas, Açıkalın ve Turan (2017) tarafindan geliştirilen "Okul Yöneticilerinin Kuantum Liderlik Davranışları Ölçĕği", Üstüner (2016) tarafından geliştirilen "Algılanan Müdür Yönetim Tarzı Ölçeği" ve Balay(2000) tarafından geliştirilen "Örgütsel Bağlllık Ölç̧ği" kullanılmıştır. Araştırma bulguları literatür taraması ve ölçeğin uygulanması sonucu elde edilen verilere dayanılarak oluşturulmuştur. Elde edilen bulgulara göre; okul yöneticilerinin kuantum liderlik davranışı sergileme düzeylerine ilişkin öğretmen görüşlerinin hem okul düzeyinde hem de cinsiyet değişkenine göre anlaml bir farklllık olmadığı, okul yöneticilerinin yönetim tarzlarına ilişkin öğretmen görüşlerinin hem okul düzeyinde hem de cinsiyet değiş̧kenine göre anlamlı bir farklllık olmadığı, öğretmenlerin örgütsel bağlllı düzeylerinin okul düzeyinde farklılaştığı ancak cinsiyet değişkenine göre anlamlı bir farklllık olmadığı sonucuna ulaşılmıştır. Kuantum liderlik davranışının hem yönetim tarzı hem de öğretmenlerin örgütsel bağlılı̆̆ı ile ilişkili olduğu ve pozitif yönde bir etkisinin olduğu bulgusuna ulaşılmıştır.

Anahtar Kelimeler: Kuantum Mekaniği, Liderlik, Okul Yöneticileri, Yönetim Tarzı, Örgütsel Bağlllık.

\footnotetext{
${ }^{1}$ Bu çalışma Methi ÇELiK'in Hacettepe Üniversitesi Eğitim Yönetimi Doktora Programında Prof. Dr. Ş.Şule ERÇETIN danışmanlığında tamamlamış olduğu "Okul Yöneticilerinin Kuantum Liderlik Davranışlarının Yönetim Tarzlarına Ve Öğretmenlerin Örgütsel Bağıılık Düzeyine Etkisi” başlıkı tezinden türetilmiştir.
} 


\title{
Analysis of Quantum Leadership in the Context of Management Styles and Organizational Commitment ${ }^{2}$
}

\begin{abstract}
According to the teachers 'opinions in this study; School administrators 'quantum leadership behavior, school administrators' management styles and teachers 'organizational commitment were analyzed according to teachers' school level and gender variables. In the research; Quantum leadership behaviors and management styles of school administrators and teachers' organizational commitment were examined within the framework of the relational scanning model. The universe of the research has constituted 47.233 teachers working in the central districts of Ankara in the 2020-2021 academic year. The stratified sampling method was used while determining the sample of the study. The "Quantum Leadership Behaviors Scale of School Administrators" developed by Ercetin, Potas, Acıkalın and Turan (2017), the "Perceived Principal Management Style Scale" developed by Üstüner (2016) and the "Organizational Commitment Scale" developed by Balay (2000) were used in the study. The research findings were created based on the data obtained as a result of the literature review and application of the scale; There is no significant difference in teachers' views on school administrators' According to the results; obtained levels of quantum leadership behavior, both at the school level and according to the gender variable, teachers' views on school administrators' management styles do not differ significantly both at the school level and according to the gender variable, teachers' organizational commitment levels differ at the school level. However, it was concluded that there was no significant difference according to the gender variable. It has been found that quantum leadership behavior is associated with both management style and teachers' organizational commitment and has positive effect on them.
\end{abstract}

Key Words: Quantum Mechanics, Leadership, School Administrators, Management Style,

Organizational Commitment.

2 This study is derived from Methi ÇELIK's thesis titled "The Effect Of School Managers ' Quantum Leadership Behavior On Management Styles And Teachers' Organizatıonal Commitment Level", which he completed under the supervision of Prof. Dr. Ş.Şule ERÇETiN in the Education Management Doctorate Program of Hacettepe University 


\section{Giriş}

Var olduğundan günümüze dek dünya üzerinde birçok medeniyetin hüküm sürdügü bilinmektedir. Bu medeniyetler tarihsel süreç içerisinde biri diğerini etkileyerek, değiştirerek bazen de tümüyle dönüştürerek yeni bir formda varlık göstermişlerdir. Bu değişim ve dönüşümün bir sonucu olarak evrene ilişkin olay ve olgular süreçle birlikte yeniden algılanmaya çalışılır. Günümüzde yaşanan değişim ve dönüşümü göz önüne aldığımızda, Kopernik'in 1543 yılında 'Göksel Kürelerin Dönüşleri Üzerine' ve Newton'un 1687'de ortaya koyduğu 'Doğa Felsefesinin Matematiksel İlkeleri' adlı eserlerinin ortaya çıkmasıyla oluşan bilimsel başarı ve gelişmeler, Batı medeniyetinde entelektüel ve kültürel hayatın dönüşümünü sağlamıştır. 'Bilim Çağı' olarak adlandırılan bu süreçte, bilim; toplumu, okulları etkilemiş, insanların fikirlerini değiştirmiş, sosyal teorisyenlere yeni bakış açıları sunmuş, insanları; alışkanlık ve geleneklere karşı tavrını değiştirerek, geçmişinden bağımsız yaşamaya (Alatlı, 2010, s.770) zemin hazırlamıştır. Newton'un "Principia" adlı kitabı çıktığ 1687 yılı ve sonrasındaki süreçte, insanlığın dünyaya ilişkin algısını, bakış açısını değiştirdiği düşünülmektedir. İnsanlığın evreni algılama biçimini yaklaşık 250 yıl etkisi altına alan Newton'un görüşleri; dünyayı kesin ve tahmin edilebilir bir şekilde değerlendirdiği için, bu dönemin bilim insanları, doğanın yasalarını mekaniksel ve matematiksel olarak incelemişlerdir. Max Planck'in, cisimlerin hem dalga hem de parçacık niteliği taşıdığına ilişkin Kuantum Kuramının temelini oluşturan görüşleri, Newton fiziğinden farklı bir algılama biçimiyle, tüm dünya da bilimi algılayış biçimimize yeni bir ufuk açmıştır. Einstein'ın konuya ilişkin çalışmalarını Bohr, Schrödinger, de Broglie, Heisenberg, gibi bilim insanlarının çalışmaları takip etmiştir. Sonrasında Born, Dirac, Gibbs, Compton gibi birçok bilim insanı, artan çalışmalarıyla bilimsel bakış açımıza yeni pencereler açan kuantum fiziğine katkıda bulunmuş ve gelişmesini sağlamışlardır(Servay, 1996, Erçetin, 2000, Zohar, 2019, Brooks, 2010, Crease ve Goldhaber, 2016). Bu araştırmanın temel konusu olan kuantum liderlik kavramı; işte bu bakış açısından esinlenerek ortaya konulmuştur. Temel varsayımları "lider ve takipçileri arasında bir etkileşim alanı, yapılandırılamaz ve tahmin edilemezlik, kesiklilik- 
süreksizlik, etkileşime bağlılık"(Erçetin, 2000) olan kuantum liderlik, geleceğimizin teminatı olan çocuklarımızın yetiştirildiği okullarda, yönetimi uhdesinde barındıran yöneticilerden sergilemeleri beklenen bir liderlik türü olduğu düşünülmektedir. Temel amacı, ülke için faydalı bilgi ve becerilerle donatılmış bireyler, yurttaşlar yetiştirmek olan okulların, amaca uygun işlemesi, yönetilmesi, gelişen ve sürekli değişen dünyaya ayak uydurması önemli bir durum olarak görülebilir. Kuantum liderlik davranışlarını benimseyen ve davranışlarıyla bunu ortaya koyan okul yöneticileri günümüz için, kendilerinden beklenen ve çağın gerekleri doğrultusunda inovasyona bağlı olarak yeterli bilgi ve donanıma sahip bireyler olarak görülebilir. Ülkemizde ve dünyada herhangi bir okulu ele aldığımızda burada görev yapan eğitim yöneticilerinin birbirinden farklı liderlik türleri ve yönetim tarzları ortaya koydukları çeşitli araştırma sonuçlarında görülebilir(Üstüner, 2016). Bu liderlik türlerinden biri olan kuantum liderliğin ilkelerini özümsemiş ve davranışlarına yansıtmış bir okul yöneticisi, çalışanlarla sürekli bir etkileşim içerisinde olur. Tüm iletişim kanallarıyla etkileşimi destekler ve çalışanlar arasında ayırım yapmaz. Kendini, okul denilen örgütün bir üyesi ve parçası olarak bilir ve çalışanların üstünde görmez. Çalışanların ihtiyaçlarını tespit ederek, bunları giderme yolları bulur ve çalışanlarla bütünleşir. Çağdaş yönetim ilkelerini takip ederek, dinamik çevrenin belirsizliğinde, olası örgütsel kaos ve karmaşıklığ1 yönetir. Yönetici ve çalışanlar farklı zaman dilimlerinde yaşanan bir olayda bir araya gelebilir veya farklı fikirlere sahip olunarak bu bir zenginlik olarak algılanabilir. Okul içerisinde, gün içinde ortaya çıabilecek herhangi bir duruma bağlı olarak liderlik el değiştirebilir. Örneğin, yaşanan bir sorunun çözümünde okulun herhangi bir çalışanı lider pozisyonunda en önde rol alabilir. Kuantum liderlik özelliklerini içselleştirmiş bir okul yöneticisi, çalışanlarını yetkilendirerek güçlendirmenin okulun amaçlarına hizmet ettiğini bilir. Çalışanlar üzerinde hüküm sürme, yargılama tutum ve davranışlarından uzak durur. Bunun tersine çalışanlara yol gösterici, danışman rollerini takip eder. Çünkü okulun gücünün, tüm çalışanların oluşturduğu ortak güç ve sinerjide olduğunu bilir. Gücü çalışanlarla paylaşarak ortak vizyonun benimsenmesini sağlar. İnformal etkileşimler sonucunda; karşıllklı güdüleme, açıklık, şeffaflık, dürüstlük, güven, rollere/kişilere saygı, öğrenme ve gelişmeyi 
devam ettirme ön planda yer alır(Erçetin, 1999, Erçetin ve Kayman, 2014, Kosa, 2020).

Hedefleri gerçekleştirmedeki görevine ilişkin davranışı ve birlikte çalıştığı çalışma arkadaşlarıyla kurduğu ilişki davranışının sonucunda vuku bulan etkileşimin oluşturduğu bir davranış örüntüsü (Başaran, 2004, s.124) olarak tanımlanan yönetim tarzı, araştırmamızın bir diğer önemli sacayağını oluşturmaktadır. Bir takım insanları belirlenen amaçlar doğrultusunda bir araya toplayabilme ve bunları gerçekleştirmek için grubu harekete geçirme yeteneği (Eren, 2008a, s.431) olarak tanımlanan liderlikten farklı olarak yönetim tarzı, en yalın ifadeyle; yöneticilerin başarıya ulaşmak için takip ettikleri rota (Rees ve Porter, 2008) olarak değerlendirilmektedir. Yüksek bir misyon yüklenen okullarda/örgütlerde belirlenen hedeflere ulaşmak üzere, yol ve süreç için karar veren, planlayan, eşgüdümleyen, sonuca ulaştıran, tasarlanarak meydana getirilen yönetim mekanizmalarını elinde bulunduran okul yöneticilerinin, yönetim sürecinde, kişisel özelliklerinden kaynaklanan negatif davranışlar olarak tanımlanan idiopatik, ya da sahip oldukları ideolojiden kaynaklanan negatif davranışlar olarak ifade edilen ideopatik davranışlar sergilemelerinin okulun yönetim sürecinde olumsuzluklara yol açması olası bir sonuçtur(Hodgkinson, 2008). Yönetsel davranışların gözlenebildiği en sağlıklı ortamlar, örgütsel ortamlar (Açıkalın, 1994, s.3) olarak karşımızda durmaktadır. Khan ve Panarina'ya göre, her örgüt birbirinden farklı birçok alışkanlık, norm, inanç, değer, gelenek ve göreneklerden oluşan bir kültüre sahiptir. Örgütteki bu değişimin, örgütün yapı, şema, iş ve tabii bir şekilde yöneticilerin yönetim tarzlarına (Özturan, 2018, s.84) yansıması olasıdır. Okul yöneticilerinin yönetsel davranış tarzlarının, okul denilen örgütlerin verimliliği ve etkililiğinin önemli bir bileşeni olduğu konusu göz önüne alındığında, sergilenen yönetsel davranışın önem kazandığı söylenebilir. Okul yöneticiliğinin bir rol olduğu zaman zaman unutulabilmektedir. Bunun sonucunda okul yöneticilerinin sergilediği yönetim tarzları da farklılaşabilmektedir. Yönetim tarzının, çalışanların birbirleriyle ve çevreyle ilişkilerini açıklayan örgütsel ekolojiye önemli ölçüde etki edebileceği varsayılmaktadır. Yönetim tarzının, örgüt üyelerinin işe bağlılığı, iş doyumu, işe karşı tutum ve davranışlarını etkileme gücüne 
sahip olduğu düşünülmektedir. Yönetim tarzının, yöneticinin sergilediği yönetsel davranışlar çerçevesinde ortaya çıktığı, yöneticinin sergilediği yönetsel davranışının türünü belirleyen ve ona hayat veren esas etmenin ise yöneticinin üstlendiği rolü gereği elde ettiği yetkiyi kullanma biçimi olduğu bilinmektedir(Üstüner, 2016). Okul yöneticilerinin yönetim tarzını belirlemeye ilişkin bu çalışmada, okul yöneticilerinin sergiledikleri yönetim tarzları; demokratik-işbirlikli, otoriter, ilgisiz ve karşı koyucu başlıkları altında ele alınmıştır. Çağımızın gerektirdiği yönetim anlayışını taşıyan, yönetişim ilkelerini benimsemiş, inovasyona açık, iletişim becerileri yüksek yöneticilerin sergileyebileceği yönetim tarzının demokratik-işbirlikli yönetim tarzı olması gerekliliği düşünülmektedir.

Araştırmamızın üçüncü sacayağını örgütsel bağlılık kavramı oluşturmaktadır. Örgüt içerisinde çalışanların burada kalma ve sadakatle hizmet etme isteği, örgütün amaç ve değerlerine karş1 duyulan bağlılık ile bu amaçların gerçekleşmesi için ortam oluşturma, özveride bulunma ve bir bakıma kendini örgüte adama (Aslan ve Bakır, 2014, s.192) tutum ve duyguları olarak tanımlanan örgütsel bağlılık okullar için önemli bir durumdur. Örgütsel bağlllı̆̆ın tüm okul çalışanlarınca içselleştirilmiş ve davranışa dönüştürülmüş olması istendik bir durum olarak değerlendirilebilir. Çünkü örgütsel bağl1lı̆̆1 yüksek düzeyde olan çalışanların bulunduğu okullarda, öğrencilerin belirlenen amaçlar çerçevesinde yetiştirilmeleri daha olasıdır. Okullarda bulunan çalışanların okullarına karşı besledikleri bağlılıkların gücü, buradaki eğitimsel etkililik kadar, toplumun topyekûn gelişmişliği için de önemlidir(Akçay Güngör, 2018, s.55). Bunun sonucunda okul dediğimiz örgütün üyesi olan öğretmenlerde, örgütün genel yapısına ve işleyişine karşı ortaya çıkan ve arzu edilen bir bağlllık durumu meydana gelmesi olasıdır. Örgütsel bağlılık kavramını; çalışanların yer aldığ 1 örgütün politika ile belirlenmiş amaçlarına sahip çıkması, görevine ilişkin gereklilikleri yerine getirmesi, örgütün geneline ait çıkarları şahsi çıkarlarının üstünde tutması; özverili bir şekilde performans sergilemesi, gerektiği zaman örgüte daha fazla zaman ayırması, maddi bağlardan öte manevi bağlarla bağlanma şeklinde ifade edilebilir(Balay, 2000). Örgütsel bağlılık düzeyi yüksek olan çalışanın performansı da olumlu etkilenerek yüksek olması sonucunda çalışanın işe devamsızlığı azalacak, geç kalma, 
işten ayrılma gibi davranışların da azalmasına zemin hazırlayacaktır. Yüksek düzeydeki örgütsel bağlılık müşteri memnuniyetini artıracak, aynı anda çalışanların örgütsel vatandaşlık davranışına da etki (Özdevecioğlu, 2003) edebilecektir.

$\mathrm{Bu}$ açılamalar ışığında, kuantum liderlik davranışını içselleştirmiş bir okul yöneticisinin, okulun iş ve işlemlerine ilişkin işleyişinde demokratik-işbirlikli bir yönetim tarzı sergilemesi beklenebilir. Çünkü kuantum liderlik davranışları, demokratik ve işbirliğine dönük bir anlayışı önceler. Kuantum liderlik davranışları sergileyen bir okul yöneticisinin anti-demokratik bir davranış içerisinde olması, çalışanlarla işbirliği içerisinde hareket etmemesi olası, beklenen bir durum değildir. Kuantum liderlik davranışının, yönetimde demokratik-işbirlikli yönetim tarzını olumlu yönde etkilediği düşünülmektedir. Diğer yandan, kuantum liderlik davranışını içselleştirmiş bir okul yöneticisinin, okulun çalışanlarına yönelik sergileyeceği olumlu tutum ve davranış sonucunda, çalışanların okula karşı bağlılıklarına pozitif yönde katkı sağlayacağı ön görüsünde bulunulabilir.

Sonuç olarak; bilim tarihi boyunca kuantum mekaniği paradigması kadar insan düşüncesi üzerinde bu denli büyük etkili olmuş bir teori daha olmamıştır(Crease ve Goldhaber, 2016, s.243) şeklindeki kuantum mekaniğine bakış açısının hayatımıza etkisi önemli bir husus olarak görülebilir. Tüm dünyayı etkileyen böylesi bir bakış açısının; yönetime ve liderliğe uyarlanmış şekli olan kuantum liderlik davranışlarının izlenmesine yönelik olarak okul yöneticilerine ilişkin alan yazında yeterli çalışmanın olmaması önemli bir problem olarak görülmektedir. Yine okul yöneticilerinin yönetim tarzları ile benzer şekilde öğretmenlerin örgütsel bağll1ık durumlarının incelenmesine ilişkin birçok çalışma varken, bunların bir arada kuantum liderlik bağlamında analizine ilişkin herhangi bir çalışmaya veya bulguya rastlanmamıştır. Bu çalışmada, örneklem dâhilindeki okullarda görev yapan okul yöneticilerinin kuantum liderlik davranışı sergileme düzeyleri, yönetim tarzları ve öğretmenlerin örgütsel bağlılık düzeylerinin bazı değişkenlere göre farklılaşıp farklılaşmadığı ortaya çıkarılarak, bunlar arasındaki ilişkinin düzeyi belirleme amaçlanmıştır. Alan yazında yapılan incelemede bu üç kavramı birlikte inceleyen, değerlendiren herhangi bir çalışmaya ulaşılamamıştır. Bu bağlamda, okul yöneticilerinin kuantum liderlik 
davranışı sergilediği, bunu demokratik ve katılımcı bir tarzla desteklediği okullarda, öğrenciler ve diğer tüm paydaşların mutlu, öğretmenlerin de kuruma yönelik örgütsel bağlllıklarının azami düzeyde olması varsayımıyla yola çıkılan bu araştırmanın hem alana, hem araştırmacılara, hem de uygulayıcılara katkı sağlayacağ düşünülmektedir. Bu araştırma, "okul yöneticilerinin kuantum liderlik davranışı sergileme düzeylerinin yönetim tarzlarına ve öğretmenlerin örgütsel bağl1lı düzeylerine etkisi nedir?" problem cümlesi çerçevesinde ortaya çıkmıştır. Araştırmada aşağıdaki sorulara yanıt aranmıştır.

1. Öğretmen görüşlerine göre; Okul Yöneticilerinin Kuantum liderlik davranışı sergileme düzeyleri; Okulların düzeyi ve Cinsiyet durumuna göre farklılaşmakta mıdır?

2. Öğretmenlere görüşlerine göre; Okul Yöneticilerinin Yönetim Tarzı; Okulların düzeyi ve Cinsiyet durumuna göre farklılaşmakta mıdır?

3. Öğretmen görüşlerine göre; öğretmenlerin örgütsel bağlllık düzeyleri Okulların düzeyi ve Cinsiyet durumuna göre farklılaşmakta mıdır?

4. Öğretmen görüşlerine göre; Okul Yöneticilerinin sergilediği Kuantum Liderlik davranışları, okul yöneticilerinin Yönetim Tarzları ve Öğretmenlerin Örgütsel Bağlılıklarıyla ilişkili midir?

\section{Yöntem}

Gerçekleştirilen bu çalışmada; 'Okul Yöneticilerinin Kuantum Liderlik Davranışlarının Yönetim Tarzlarına Ve Öğretmenlerin Örgütsel Bağlılık Düzeyine Etkisi Nedir?' problem cümlesi ilişkisel tarama modeli çerçevesinde incelenmiştir. Tarama modelleri geçmişte yahut bugün de varlık gösteren bir olguyu, durumu mevcut şekli ile betimlemeyi hedefleyen ve sıklıkla kullanılan bir araştırma yaklaşımıdır. Modelin bir alt birimi olarak ilişkisel tarama modelindeyse; iki veya daha çok sayıda değişken arasında birlikte değişim varlık ve/veya derecesinin tespitine yönelik bir işlem yapılır(Karasar, 2008, s.81-87). Bu araştırmada bu amaca en uygun model olduğu varsayımıla ilişkisel tarama modeli kullanılmıştır. Buna ilişkin model Şekil 1.'de yer almaktadır. Araştırma 
bulguları literatür taraması ve ölçeğin uygulanması sonucu elde edilen verilere dayanılarak oluşturulmuştur.

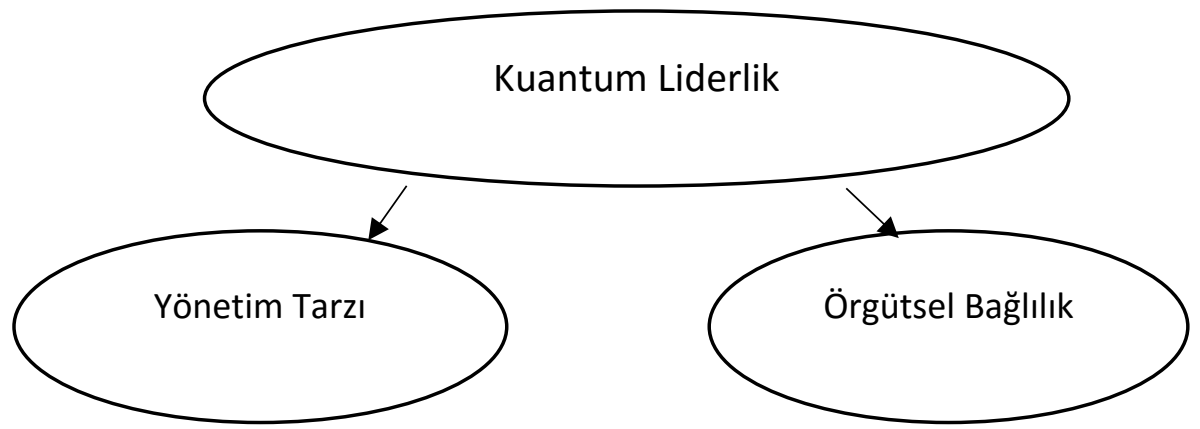

Şekil 1. Kuantum Liderliğin Yönetim Tarzına ve Örgütsel Bağlılı̆̆a Etkisi

\section{Örneklem}

Araştırmanın evreni 2020 - 2021 eğitim öğretim yılında Ankara İli merkez ilçeleri Çankaya, Keçiören, Altındağ, Yenimahalle, Etimesgut, Mamak, Gölbaşı, Sincan ve Pursaklar'da bulunan toplam 1.233 ilköğretim ve ortaöğretim kurumlarında görev yapan 47.233 öğretmen oluşturmuştur. Araştırmaya ilişkin Hacettepe Üniversitesi Etik Komisyonundan 28.12.2020 tarih ve 1376855 sayılı yazıyla gerekli izinler alınmıştır. Verilerin toplanmasına ilişkin Ankara İl Milli Eğitim Müdürlüğ̈̈'nden de 11.02.2021 tarih ve 20545768 sayılı yazıyla gerekli izinler alınmıştır.

Araştırmanın örneklemi belirlenirken tabakalı örnekleme yöntemi kullanılmıştır. Tabakalama işleminde ilçeler temel alınmıştır.

Tablo 1. Evren ve Örnekleme İlişkin Veriler

\begin{tabular}{lllll}
\hline İçe Adı & $\begin{array}{l}\text { Kurum } \\
\text { Sayısı }\end{array}$ & $\begin{array}{l}\text { Öğretmen ve } \\
\text { Yönetici Toplam } \\
\text { Sayısı } \\
\text { (Yığın Sayısı) }\end{array}$ & Oran & $\begin{array}{l}\text { Öğretmen Sayısı } \\
\text { (Örneklem } \\
\text { Miktarı) }\end{array}$ \\
\hline Altındağ & 144 & 4.669 & 0,099 & 103 \\
Çankaya & 219 & 7.761 & 0,164 & 172 \\
Etimesgut & 95 & 5.079 & 0,108 & 112 \\
Gölbaşı & 126 & 1.636 & 0,035 & 36 \\
Keçiören & 155 & 7.995 & 0,169 & 177 \\
Mamak & 179 & 5.882 & 0,125 & 130 \\
Pursaklar & 39 & 1.542 & 0,033 & 34
\end{tabular}




\begin{tabular}{lllll} 
Sincan & 123 & 5.641 & 0,119 & 125 \\
Yenimahalle & 153 & 7.028 & 0,149 & 155 \\
Toplam & 1233 & 47.233 & 1 & 1044 \\
\hline
\end{tabular}

Kaynak: http://ankara.meb.gov.tr/www/egitim-istatistikleri/icerik/24 adresinden 13.06.2020 tarihinde alınmıştır. (Not: Tez verileri çerçevesinde burada sadece <982> öğretmen görüşleri dikkate alınacaktır.)

"Kuantum Liderlik", "Yönetim Tarzı" ve "Örgütsel Bağlılık" ölçeklerinden oluşan araştırma veri toplama anketinin uygulanması için gerekli izin alındıktan sonra covid 19 salgın sürecinden kaynaklı olarak, alınan izin çerçevesinde elektronik veri toplama aracıyla örneklem dâhilindeki okullarla iletişim kurularak anket öğretmenlere uygulanmiştır.

\section{Kullanılan Veri Toplama Araçları}

Araştırmada katılımcının kişisel bilgilerinin yanında aşağıdaki üç farklı veri toplama aracı kullanılarak veriler toplanmıştır.

Birinci veri toplama aracı. Araştırmamızın birinci sacayağında Erçetin, Potas, Açıkalın ve Turan (2017) tarafından okul müdürlerinin kuantum liderlik davranışlarını sergileme durumlarını ortaya çıkarmayı hedefleyen "Okul Yöneticilerinin Kuantum Liderlik Davranışları Ölçeği" (OYKLDÖ) kullanılmıştır. Bunun için gerekli izin alınmıştır. Beşli Likert tipinde hazırlanan ölçek; her zaman (5), çoğu zaman (4), ara sıra (3), çok nadir (2) ve hiçbir zaman (1) şeklinde düzenlenmiştir. Burada; Liderlik, lider-izleyenler ikileminde bir etkileşim alanıdır(9), Liderlik yapılandırılamaz ve kestirilemez(9), Liderlik olgusunun Kesikliliği(10), Liderliğin etkisi etkileşime dayalıdır(10) olmak üzere 4 boyut ve 38 madde yer almaktadır. OYKLDÖ'na yönelik araştırmacılar tarafından gerçekleştirilen standartlaştırılmış yük değerlerinin ölçeğin ilk boyut için .88 ile .79 , ikinci boyut için .88 ile .71 , üçüncü boyut için .88 ile .62 ve dördüncü boyut için .87 ile .65 arasında değiştiği izlenmiştir. Ölçeğin Cronbach's Alfa katsayılarına bakıldığında ölçeğin birinci boyutu için .77 ile .91, ikinci boyutu için .77 ile .89 , üçüncü boyutu için .63 ile .86 ve dördüncü boyut için .70 ile .86 arasında değişirken kullanılan ölçeğin güvenirlik katsayısı birinci boyutta .97 , ikinci boyutta .96 , üçüncü boyutta .96 ve dördüncü boyutta .95 değerindedir. Ölçeğin tümüne 
ilişkin güvenirlik katsayısı ise .98 olarak gerçekleşmiştir. Araştırmaya ilişkin geçerlik ve güvenirlik çalışmaları Araştırmacılar tarafından gerçekleştirilmiş ve uygulanabilir olarak görülmüştür.

İkinci veri toplama aracı. Araştırmada okul müdürlerinin yönetim tarzlarına ilişkin Üstüner (2016) tarafından geliştirilen "Algılanan Müdür Yönetim Tarzı Ölçeği" kullanılmıştır. Bunun için gerekli izin alınmıştır. Ölçeğin bu bölümü; İşbirlikçi (7), Otoriter (7), İlgisiz (7) ve Karşı Koyucu Yönetim Tarzı (4) olmak üzere 4 boyut ve 25 maddeden oluşmaktadır. Üstüner (2016) tarafından yapılan güvenirlik analizleri 0,740 olarak hesaplanan ölçek, (1) Hiçbir zaman, (2) Nadiren, (3) Bazen, (4) Çoğu zaman, (5) Her zaman şeklinde beşli likert tipi olarak düzenlenmiştir. Araştırmacı tarafından gerçekleştirilen güvenirlik düzeyini belirleme çalışmasında alt boyutlar için hesaplanan Cronbach's Alfa katsayıları; işbirlikli yönetim tarzı alt boyutunda .92, otoriter yönetim tarzı alt boyutunda .89 , ilgisiz yönetim tarzı alt boyutunda .86 ve karşı koyucu yönetim tarzı alt boyutunda .85 olarak bulunmuştur.

Üçüncü veri toplama aracı. Araştırmada öğretmenlerin örgütsel bağlılık düzeylerini belirlemeye ilişkin Balay(2000) tarafından geliştirilen "Örgütsel Bağlllık Ölçeği” kullanılmıştır. Bunun için gerekli izin alınmıştır. Ölçeğin bu bölümü; (1) Hiç katılmıyorum, (2) Az katılıyorum, (3) Orta Düzeyde Katılıyorum, (4) Çok Katılıyorum, (5) Tam Katılıyorum şeklindeki seçeneklerinden meydana gelmektedir. Veri toplama arac1; Uyum (8), Özdeşleşme (8) ve İçselleştirme (11) olmak üzere toplam 27 maddeden oluşmaktadır. Balay (2000) tarafından geliştirilen ölçeğin Araştırmacı tarafından hesaplanan Cronbach Alfa katsayısı Uyum için .79, Özdeşleşme için .89 ve İçselleştirme için .93 olarak tespit edilmiştir. $\mathrm{Bu}$ bulgular çerçevesinde kullanılan ölçek geçerli ve güvenilir bir ölçme aracıdır diyebiliriz. Araştırmamızda kullandığımız ölçeklere ilişkin her bir ölçeğin total olarak hesaplanan Cronbach Alfa Katsayısı değerleri aşağıda Tablo 2.'de yer almaktadır.

Tablo 2. Değişkenlere İlişkin Cronbach Alfa Katsayısı Değerleri

\begin{tabular}{lll}
\hline & Cronbach Alfa & Madde \\
Ölçekler & Katsayısı & Sayısı \\
\hline Kuantum Liderlik Ölçeği & 0.988 & 38 \\
Yönetim Tarzı Ölçeği & 0.906 & 25 \\
Örgütsel Bağlılık & 0.792 & 27 \\
Toplam Madde Sayısı & & 90 \\
\hline
\end{tabular}


Tablodan da anlaşıldığı şekilde ölçeklerin referans aralığı psikolojik bir ölçme aracı için hesaplanan güvenirlik katsayısının 0.70 ve fazlası olması ölçme aracı puanlarının güvenirliği için (Büyüköztürk, 2012, s.171) yeterli olduğunu göstermektedir. Bu çerçevede yukarıdaki sonuçlara göre 982 katılımcıdan toplanmış olan veri setine dayalı olarak Kuantum Liderlik ölçeği toplam Cronbach Alfa katsayısı .98, Yönetim Tarzı ölçeği Cronbach Alfa katsayısı .90 ve Örgütsel Bağlılık Ölçeği Cronbach Alfa katsayısı .79 olarak güvenilir oldukları genel sonucuna ulaşılmıştır.

\section{Bulgular}

Öğretmenlere göre; okul yöneticilerinin Kuantum Liderlik davranışı sergileme düzeyleri;

a) Okul düzeyine göre istatistiksel bakımdan önemli düzeyde farklılık göstermekte midir?

Öğretmenlerin görev yaptıkları okul düzeyleri ile yöneticilerinden algıladıkları kuantum liderlik davranışları arasındaki ilişkiyi açığa çıkarabilmek için çalıştıkları işyerlerine bağlı olarak öğretmenler "Anaokulu", "İlkokul", "Ortaokul" ve "Lise" olmak üzere dört grupta sinıflandırılmış ve bu grupların algıladıkları kuantum liderlik düzeylerine ilişkin betimsel ve çıarımsal istatistikleri Tablo 3'te gösterilmiştir.

Tablo 3. Öğretmenlerin Okul Düzeylerine Göre Algıladıklan Kuantum Liderlik Düzeylerine İlişkin Betimsel ve Çıkarımsal İstatistikler

\begin{tabular}{|c|c|c|c|c|c|c|c|c|c|c|}
\hline \multirow[t]{2}{*}{ Ölçekler } & \multicolumn{2}{|c|}{ Anaokulu $(n=37)$} & \multicolumn{2}{|l|}{$\begin{array}{l}\text { İlkokul } \\
(\mathrm{n}=366)\end{array}$} & \multicolumn{2}{|l|}{$\begin{array}{l}\text { Ortaokul } \\
(n=305)\end{array}$} & \multicolumn{2}{|l|}{$\begin{array}{l}\text { Lise } \\
(\mathrm{n}=274)\end{array}$} & \multirow[t]{2}{*}{$\mathbf{F}(3,978)$} & \multirow[t]{2}{*}{$\eta_{p}^{2}$} \\
\hline & $\overline{\bar{x}}$ & SS & $\overline{\bar{x}}$ & SS & $\overline{\bar{x}}$ & SS & $\overline{\bar{x}}$ & SS & & \\
\hline $\begin{array}{l}\text { Liderlik, lider-izleyenler } \\
\text { ikileminde bir etkileşim } \\
\text { alanıdır }\end{array}$ & 41.35 & 4.08 & 41.16 & 6.54 & 40.32 & 7.18 & 38.36 & 9.36 & $7.66^{*}$ & .02 \\
\hline $\begin{array}{l}\text { Liderlik yapılandırılamaz } \\
\text { ve kestirilemez }\end{array}$ & 39.62 & 5.12 & 39.39 & 7.58 & 38.37 & 7.66 & 35.92 & 10.10 & $9.75^{*}$ & .03 \\
\hline $\begin{array}{l}\text { Liderlik olgusunun } \\
\text { kesikliliği }\end{array}$ & 45.32 & 5.15 & 44.35 & 7.76 & 43.63 & 8.58 & 41.14 & 10.84 & $7.86^{*}$ & .02 \\
\hline $\begin{array}{l}\text { Liderliğin etkisi } \\
\text { etkileşime dayalıdır }\end{array}$ & 43.24 & 5.13 & 43.35 & 7.54 & 42.67 & 7.96 & 40.57 & 10.20 & $6.07^{*}$ & .02 \\
\hline
\end{tabular}

* Ardışık Bonferroni düzeltmesi yapıldı, $\eta_{p}^{2}$ : Kısmi eta-kare, $p<.05$ 
Tablo 3.'te dört alt ölçekte de gruplar arasındaki puan ortalaması farkının önemli olduğunu göstermektedir. Grupların varyansları homojen olmadığında post hoc test olarak seçilen Dunnet $C$ testine göre, "Liderlik, lider-izleyenler ikileminde bir etkileşim alanıdır" ve "Liderlik olgusunun kesikliliği" alt ölçeklerinde anaokulu, ilkokul ve ortaokul öğretmenlerinin puan ortalamaları arasında fark bulunmamaktadır. Anaokulu ve ilkokul öğretmenleri lise öğretmenlerinden daha yüksek puanlara sahiptir; ortaokul ve lise öğretmenleri arasındaki puan farkı ise önemsizdir. "Liderlik yapılandırılamaz ve kestirilemez" alt ölçeğinde anaokulu, ilkokul ve ortaokul öğretmenleri lise öğretmenlerinden daha yüksek puan ortalamasına sahiptirler. Yani bu alt boyuta ilişkin ifadelere anaokulu, ilkokul ve ortaokul öğretmenlerinin daha çok katıldıkları söylenebilir. "Liderliğin etkisi etkileşime dayalıdır" alt ölçeğinde ilkokul öğretmenleri lise öğretmenlerinden daha yüksek puan ortalamasına sahip olduğu; diğer ikili karşılaştırmalarda ise farkların önemsiz olduğu bulunmuştur. Önemli etkiler için testin gücü .95 ten büyük olmakla birlikte, $\eta_{p}^{2 \prime}$ ler okul düzeyinin algılanan kuantum liderlik davranışı üzerindeki etkisinin küçük olduğunu göstermektedir. Bu bulgular 1şığında öğretmen görüşlerine göre; okul yöneticilerinin kuantum liderlik davranışı sergileme düzeyleri okul düzeyine göre istatistiksel bakımdan önemli düzeyde farklılık göstermemekle birlikte Anaokulu ve İlkokulda görev yapan öğretmenlerin "Liderlik, lider-izleyenler ikileminde bir etkileşim alanıdır" ve "Liderlik olgusunun kesikliliği" alt ölçeklerindeki ifadelere Lise öğretmenlerinden daha yüksek puanlar verdikleri söylenebilir. "Liderlik yapılandırılamaz ve kestirilemez" alt ölçeğinde ise Anaokulu, İlkokul ve Ortaokul öğretmenleri Lise öğretmenlerine göre ifadelere daha yüksek puanlar verdikleri görülebilir. Bu bulgu Erçetin vd. (2018) tarafından gerçekleştirilen araştırma bulgularıyla örtüşmektedir. .

b) Cinsiyetlerine göre istatistiksel bakımdan önemli düzeyde farklılık göstermekte midir?

Öğretmenlerin cinsiyetleri ile kuantum liderlik davranışları arasındaki ilişkiyi açığa çıkarabilmek için cinsiyetlerine göre öğretmenler "Kadın" ve "Erkek" olmak üzere iki grupta sınıflandırılmış ve bu 
grupların algıladıkları kuantum liderlik düzeylerine ilişkin betimsel ve çıkarımsal istatistikleri Tablo 4.'te gösterilmiştir.

Tablo 4. Öğretmenlerin Cinsiyetlerine Göre Algıladıkları Kuantum Liderlik Düzeylerine İlişkin Betimsel ve Çıkarımsal İstatistikler

\begin{tabular}{|c|c|c|c|c|c|c|}
\hline \multirow[t]{2}{*}{ Ölçekler } & \multicolumn{2}{|c|}{$\begin{array}{l}\text { Kadın } \\
(n=669)\end{array}$} & \multicolumn{2}{|c|}{$\begin{array}{l}\text { Erkek } \\
(\mathrm{n}=313)\end{array}$} & \multirow[t]{2}{*}{$\mathbf{t}(980)$} & \multirow[t]{2}{*}{ Cohen $d$} \\
\hline & $\overline{\bar{x}}$ & SS & $\overline{\bar{x}}$ & SS & & \\
\hline $\begin{array}{l}\text { Liderlik, lider-izleyenler ikileminde } \\
\text { bir etkileşim alanıdır }\end{array}$ & 39.95 & 7.82 & 40.51 & 7.21 & -1.09 & .07 \\
\hline $\begin{array}{l}\text { Liderlik yapılandırılamaz ve } \\
\text { kestirilemez }\end{array}$ & 37.94 & 8.69 & 38.49 & 7.82 & -0.99 & .07 \\
\hline Liderlik olgusunun kesikliliği & 43.07 & 9.22 & 43.68 & 8.46 & -1.02 & .07 \\
\hline $\begin{array}{l}\text { Liderliğin etkisi etkileşime } \\
\text { dayalıdır }\end{array}$ & 42.06 & 8.83 & 42.99 & 7.69 & -1.67 & .11 \\
\hline
\end{tabular}

* Ardışık Bonferroni düzeltmesi yapıldı

Tablo 4.'te dört alt ölçekte gruplar arasındaki farkın önemsiz olduğunu göstermektedir. Ayrıca Cohen $d^{\prime}$ ler de öğretmen cinsiyetinin algılanan kuantum liderlik davranışı üzerindeki etkisinin küçük olduğunu göstermektedir. Bu bulgular ışığında öğretmen görüşlerine göre okul yöneticilerinin kuantum liderlik davranışı sergileme düzeyleri, cinsiyet değişkenine göre istatistiksel bakımdan manidar düzeyde farklılık göstermemektedir. Yani erkek veya kadın öğretmenler okul yöneticilerinin sergiledikleri kuantum liderlik davranışı düzeylerine ilişkin algıları üzerinde anlamlı bir etkisinin olmadığı, öğretmenlerin okul yöneticilerinin sergiledikleri kuantum liderlik davranışları düzeyine ilişkin birbirlerine benzer görüşleri paylaştı̆̆ 1 söylenebilir. Bu bulgu Turan (2017), Erçetin vd. (2018) ve Tufan (2019) tarafından gerçekleştirilen araştırma bulgularıyla örtüşmektedir.

Öğretmenlere göre; okul yöneticilerinin Yönetim Tarzı;

c) Okul düzeyine göre yönetim tarzı puan ortalamaları istatistiksel bakımdan önemli düzeyde farklılık göstermekte midir?

Öğretmenlerin görev yaptıkları okul düzeyleri ile algıladıkları yönetici tarzları arasındaki ilişkiyi açığa çıkarabilmek için çalıştıkları işyerlerine bağlı olarak öğretmenler "Anaokulu", "İlkokul", "Ortaokul" ve "Lise" olmak üzere dört grupta sınıflandırılmış ve bu grupların algıladıkları liderlik tarzlarına ilişkin betimsel ve çıarımsal istatistikler Tablo 5'te gösterilmiştir. 
Tablo 5. Öğretmenlerin Okul Düzeylerine Göre Algıladıklan Liderlik Tarzlarına İlişkin Betimsel ve Çıkarımsal İstatistikler

\begin{tabular}{|c|c|c|c|c|c|c|c|c|c|c|}
\hline \multirow[t]{2}{*}{ Ölçekler } & \multicolumn{2}{|c|}{$\begin{array}{l}\text { Anaokulu } \\
(\mathrm{n}=37)\end{array}$} & \multicolumn{2}{|l|}{$\begin{array}{l}\text { İlkokul } \\
(\mathrm{n}=366)\end{array}$} & \multicolumn{2}{|c|}{$\begin{array}{l}\text { Ortaokul } \\
(n=305)\end{array}$} & \multicolumn{2}{|l|}{$\begin{array}{l}\text { Lise } \\
(n=274)\end{array}$} & \multirow[t]{2}{*}{$F_{(3,978)}$} & \multirow[t]{2}{*}{$\eta_{p}^{2}$} \\
\hline & $\overline{\bar{x}}$ & SS & $\overline{\bar{x}}$ & SS & $\overline{\bar{x}}$ & SS & $\overline{\bar{x}}$ & SS & & \\
\hline İşbirlikli & 31.73 & 3.54 & 31.77 & 5.35 & 30.81 & 6.13 & 29.17 & 7.58 & $9.49^{*}$ & .03 \\
\hline Otoriter & 14.16 & 4.88 & 15.98 & 7.49 & 17.63 & 8.28 & 17.96 & 7.86 & $5.81^{*}$ & .02 \\
\hline İlgisiz & 11.59 & 4.09 & 11.68 & 6.24 & 13.06 & 7.41 & 13.69 & 7.65 & $5.03^{*}$ & .02 \\
\hline Karşı koyucu & 6.46 & 2.68 & 6.94 & 4.20 & 7.57 & 4.51 & 8.45 & 5.04 & $6.62^{*}$ & .02 \\
\hline
\end{tabular}

* Ardışık Bonferroni düzeltmesi yapıldı $\eta_{p}^{2}$ : Kısmi eta-kare

Tablo 5. dört alt ölçekte de gruplar arasındaki puan ortalaması farkının önemli olduğunu göstermektedir. Dunnet $C$ testine göre, "İşbirlikli" alt ölçeğinde anaokulu ve ilkokul öğretmenlerinin Lise öğretmenlerinden daha yüksek puan aldıklarını, "karşı koyucu" ölçeğinde daha düşük puan aldıklarını ortaya koymaktadır. "Otoriter" alt ölçeğinde anaokulu öğretmenlerinin ortaokul ve lise öğretmenlerinden; ilkokul öğretmenlerinin ise liselerde görev yapan öğretmenlerden daha düşük puan aldıklarını göstermektedir. Ayrıca Dunnet C'ye göre "İlgisiz" alt ölçeğinde ilkokuldaki yöneticiler lisede görev yapan yöneticilerden daha düşük puan almışlardır. Önemli etkiler için testin gücü .90 'dan büyük olmasına karşın, $\eta_{p}^{2 \prime}$ ler öğretmenlerin görev yaptıkları okul düzeyinin algılanan yönetim tarzları üzerindeki etkisinin küçük olduğunu göstermektedir. $\mathrm{Bu}$ bulgular ş̧ığında öğretmen görüşlerine göre okul yöneticilerinin yönetim tarzının okul düzeyi değişkenine göre istatistiksel bakımdan anlamlı düzeyde bir farklılık olmadığı söylenebilir. Ancak; okul yöneticisinin yönetim tarzına ilişkin okul düzeyi değişkenine göre; Anaokulu ve İlkokullarda görev yapan öğretmenlerin okul yöneticilerini Liselerde görev yapan öğretmenlerden daha demokratik-işbirlikli buldukları söylenebilir. Ortaokul ve Lisede görev yapan öğretmenlerin okul yöneticilerini, Anaokulu ve İlkokul öğretmenlerinden farklı olarak daha otoriter gördükleri söylenebilir. Yine yukarıdaki bulgular ışığında Lisede görev yapan öğretmenlerin okul yöneticilerini diğer gruplardan farklı olarak daha fazla "ilgisiz" ve "karşı koyucu" olarak algıladıkları söylenebilir. Öğretmenlerin okul yöneticilerinin yönetim tarzlarına ilişkin olumlu 
görüşleri Anaokulu-İlkokul-Ortaokul ve Lise şeklinde sıralanmaktadır. Burada hem Anaokulu hem de İlkokullarda görev yapan öğretmenlerin tek bir sınıfla ilgilendiklerinden, kısmen bağımsız hareket alanına sahip olduklarından kaynaklı okul yöneticilerinin yönetim tarzlarına daha az muhatap olduklarından, daha olumlu görüş taşıyarak daha yüksek puanlar vermiş olabilirler. Bu bulgular kısmen Kahraman(2019) tarafından yürütülen çalışmayla örtüşmektedir.

d) Öğretmenlerin cinsiyetlerine göre yönetim tarzı puan ortalamaları istatistiksel bakımdan önemli düzeyde farklılık göstermekte midir?

Öğretmenlerin cinsiyetleri ile yönetim tarzları arasındaki ilişkiyi açığa çıkarabilmek için cinsiyetlerine göre öğretmenler "Kadın" ve "Erkek" olmak üzere iki grupta sınıflandırılmış ve bu grupların algıladıkları yönetim tarzlarına ilişkin betimsel ve çıkarımsal istatistikler Tablo 6.'da gösterilmiştir.

Tablo 6. Öğretmenlerin Cinsiyetlerine Göre Algıladıkları Yönetim tarzlarına İlişkin Betimsel ve Çıkarımsal İstatistikler

\begin{tabular}{|c|c|c|c|c|c|c|}
\hline \multirow[t]{2}{*}{ Ölçekler } & \multicolumn{2}{|l|}{$\begin{array}{l}\text { Kadın } \\
(\mathrm{n}=669)\end{array}$} & \multicolumn{2}{|l|}{$\begin{array}{l}\text { Erkek } \\
(\mathrm{n}=313)\end{array}$} & \multirow[t]{2}{*}{$\mathrm{t}_{(980)}$} & \multirow[t]{2}{*}{ Cohen $d$} \\
\hline & $\bar{x}$ & SS & $\bar{x}$ & SS & & \\
\hline İşbirlikli & 30.51 & 6.61 & 31.25 & 5.61 & -1.81 & .12 \\
\hline Otoriter & 16.48 & 7.68 & 18.03 & 8.04 & $-2.89^{*}$ & .20 \\
\hline İlgisiz & 12.28 & 6.45 & 13.50 & 8.03 & $-2.36^{*}$ & .17 \\
\hline Karşı koyucu & 7.36 & 4.37 & 7.93 & 4.87 & 1.77 & .12 \\
\hline
\end{tabular}

* Ardışık Bonferroni düzeltmesi yapıldı

Tablo 6. "Otoriter" ve "İlgisiz" ölçeklerinde kadın ve erkekler arasındaki farkın önemli, diğer iki ölçekteki farkların önemsiz olduğunu göstermektedir. Puan ortalamaları erkek öğretmenlerin kadınlara göre yöneticilerini daha otoriter ve ilgisiz algıladıklarını ortaya koymaktadır. "Otoriter" için testin gücü .83'tür. Bununla birlikte, "İlgisiz" için .69 olup, iki alt ölçek için de cohen $d^{\prime}$ ler öğretmen cinsiyetinin algılanan yönetim tarzı üzerindeki etkisinin küçük (önemsiz) olduğunu göstermektedir. Bu bulgular 1şığında öğretmen görüşlerine göre okul yöneticilerinin yönetim tarzının cinsiyet değişkenine göre istatistiksel bakımdan anlamlı düzeyde bir farklılık olmadığı söylenebilir. Yani okul yöneticisinin yönetim tarzına ilişkin okul düzeyi değişkenine göre 
öğretmen görüşlerinin birbirine yakın seyrettiği söylenebilir. Ancak; puan ortalamalarına göre erkek öğretmenlerin kadınlara göre yöneticilerini daha otoriter ve ilgisiz algıladıkları söylenebilir. Bu bulgu Yağ (2019), Şat (2018) ve İşeri (2019)'nin yaptıkları çalışmalar ile örtüşmektedir. Kahraman(2019) tarafından yürütülen çalışmayla ise çelişmektedir. Kahraman (2019)'ın çalışmasında cinsiyet değişkenine göre yöneticilerin yönetim tarzlarına ilişkin algılar incelendiğinde yöneticilerinin yönetim tarzına ilişkin görüşleri arasında anlamlı farklılık olmadığını, yönetim tarzları algılarında kadın ve erkek öğretmenlerin görüşlerinin örtüşmekte olduğunu ifade etmektedir.

Öğretmenlere göre; öğretmenlerin Örgütsel Bağlllık düzeyi;

e) Görev yaptıkları okul düzeyine göre örgütsel bağlılık puan ortalamaları istatistiksel bakımdan önemli düzeyde farklılık göstermekte midir?

Öğretmenlerin görev yaptıkları okul düzeyleri ile örgütsel bağlılıkları arasındaki ilişkiyi açığa çıkarabilmek için çalıştıkları işyerlerine bağlı olarak öğretmenler "Anaokulu", "İlkokul", "Ortaokul" ve "Lise" olmak üzere dört grupta sınıflandırılmış ve bu grupların örgütsel bağlılıklarına ilişkin betimsel ve çıkarımsal istatistikler Tablo 7'de gösterilmiştir.

Tablo 7. Öğretmenlerin Okul Düzeylerine Göre Örgütsel Bağlılıklarına İlişkin Betimsel ve Çıkarımsal İstatistikler

\begin{tabular}{|c|c|c|c|c|c|c|c|c|c|c|}
\hline \multirow[t]{2}{*}{ Ölçekler } & \multicolumn{2}{|c|}{$\begin{array}{l}\text { Anaokulu } \\
(\mathrm{n}=37)\end{array}$} & \multicolumn{2}{|c|}{$\begin{array}{l}\text { İlkokul } \\
(n=366)\end{array}$} & \multicolumn{2}{|c|}{$\begin{array}{l}\text { Ortaokul } \\
(\mathrm{n}=305)\end{array}$} & \multicolumn{2}{|c|}{$\begin{array}{l}\text { Lise } \\
(\mathrm{n}=274)\end{array}$} & \multirow[t]{2}{*}{$\mathrm{F}_{(3,978)}$} & \multirow[t]{2}{*}{$\eta_{p}^{2}$} \\
\hline & $\bar{x}$ & SS & $\bar{x}$ & SS & $\bar{x}$ & SS & $\bar{x}$ & SS & & \\
\hline Uyum & 11.86 & 3.97 & 12.65 & 5.89 & 14.54 & 7.15 & 14.69 & 7.68 & $7.33^{*}$ & .02 \\
\hline Özdeşleşme & 32.62 & 6.73 & 32.28 & 6.79 & 30.81 & 7.22 & 29.93 & 8.36 & $6.04^{*}$ & .02 \\
\hline İçselleştirme & 48.95 & 4.72 & 47.97 & 6.69 & 46.87 & 7.33 & 46.93 & 7.75 & 2.33 & .01 \\
\hline
\end{tabular}

* Ardışık Bonferroni düzeltmesi yapıldı

$\eta_{p}^{2}$ : Kısmi eta-kare

Tablo 7 "Uyum" ve “Özdeşleşme" ölçeklerinde gruplar arasındaki puan ortalaması farklarının önemli olduğunu göstermektedir. Dunnet C testine göre, "Uyum” alt ölçeğinde Anaokulu ve İlkokul öğretmenlerinin Ortaokul ve Lise öğretmenlerinden daha yüksek puan aldıkları, diğer ikili karşılaştırmalar arasında fark olmadığını ortaya koymaktadır. Ayrıca “Özdeşleşme" ölçeğinde Anaokulu ve İlkokul öğretmenlerinin Lise öğretmenlerinden daha yüksek puanlar aldıklarını göstermektedir. 
Bununla birlikte, önemli etkiler için testin gücü $.95^{\prime}$ ten büyük olmasına karşın $\eta_{p}^{2 \prime}$ ler öğretmenlerin görev yaptıkları okul düzeyinin "Uyum” ve “Özdeşleşme" puanları üzerindeki etkisinin küçük olduğunu göstermektedir. $\mathrm{Bu}$ bulgular ışığında öğretmen görüşlerine göre öğretmenlerin örgütsel bağlllık düzeyi okul türü değişkenine göre "Uyum" ve "Özdeşleşme" ölçeklerindeki puan ortalaması farklarının önemli olduğunu, "İçselleştirme" alt boyutuna göre istatistiksel bakımdan anlamlı düzeyde bir farklılık olmadığı söylenebilir. Burada öğretmen görüşleri çerçevesinde Anaokulu ve İlkokullarda görev yapmakta olan öğretmenlerin okula yönelik örgütsel bağlılık durumları daha olumlu olarak algılanmaktadır denilebilir. Bunun sebebi olarak Anaokulu ve Sınıf öğretmenlerinin kendilerine ait bir odaları/sınıfları olması, sürekli aynı sınıfta bulunmasından kaynaklı sahiplenme ve bağlılık duygularının gelişim düzeyi olabilir. Bu bulgu Özdemir (2020) tarafından yapılan araştırma sonuçlarıyla örtüşmektedir.

f) Öğretmenlerin cinsiyetlerine göre örgütsel bağlllık puan ortalamaları istatistiksel bakımdan önemli düzeyde farklılık göstermekte midir?

Öğretmenlerin cinsiyetleri ile örgütsel bağlılıkları arasındaki ilişkiyi açığa çıkarabilmek için cinsiyetlerine göre öğretmenler "Kadın" ve "Erkek" olmak üzere iki grupta sinıflandırılmış ve bu grupların algıladıkları örgütsel bağlılık puanlarına ilişkin betimsel ve çıkarımsal istatistikler Tablo 8'de gösterilmiştir.

Tablo 8. Öğretmenlerin Cinsiyetlerine Göre Örgütsel Bağlılıklarına İlişkin Betimsel ve Çıkarımsal İstatistikler

\begin{tabular}{lcccccc}
\hline \multirow{2}{*}{ Ölçekler } & $\begin{array}{l}\text { Kadnn } \\
(\mathbf{n = 6 6 9 )}\end{array}$ & \multicolumn{3}{c}{$\begin{array}{l}\text { Erkek } \\
(\mathbf{n}=\mathbf{3 1 3})\end{array}$} & \multirow{2}{*}{$\mathbf{F}_{(1,980)}$} & Cohen $\boldsymbol{d}$ \\
\cline { 2 - 5 } & $\overline{\boldsymbol{x}}$ & $\mathbf{S S}$ & $\overline{\boldsymbol{x}}$ & $\mathbf{S S}$ & & \\
\hline Uyum & 13.28 & 6.15 & 14.84 & 8.02 & $-3.36^{*}$ & .22 \\
Özdeşleşme & 30.92 & 7.51 & 31.73 & 7.29 & -1.57 & .11 \\
İçselleştirme & 47.28 & 7.13 & 47.57 & 7.22 & -0.57 & .04 \\
\hline
\end{tabular}

* Ardışık Bonferroni düzeltmesi yapıldı

Tablo 8.'de "Uyum" ölçeğinde kadın ve erkek öğretmenler arasındaki puan farkın önemli, diğer iki ölçekteki farkların önemsiz olduğunu göstermektedir. Puan ortalamaları erkek öğretmenlerin kadınlara göre "Uyum" puanlarının daha yüksek olduğunu ortaya koymaktadır. 
"Uyum" alt ölçeğine ilişkin testin gücü $.89^{\prime}$ dur. Bununla birlikte, Cohen d'ler öğretmen cinsiyetinin "Uyum" puanları üzerindeki etkisinin küçük (önemsiz) olduğunu göstermektedir. Bu bulgular 1şığında öğretmen görüşlerine göre; öğretmenlerin örgütsel bağlllık düzeyi cinsiyet değişkenine göre "Uyum" alt boyutunda erkekler lehine bir puan farkı görülmesine karşın istatistiksel bakımdan anlamlı düzeyde bir farklılık olmadığ 1 söylenebilir. Bu küçük fark erkek öğretmenlerin örgütsel bağlılık anlamında başlangıçta daha hızlı bir uyumları ile ele alınabilir. Bu bulgu Özdemir (2020) tarafından yapılan araştırma sonuçlarıyla örtüşmektedir. Olgungül (2017) yaptığ1 çalışma ile örtüşmemektedir. Olgungül (2017) yaptığı çalışmada kadın çalışanların örgütsel bağlılıklarının, "Duygusal-Tutumsal Bağlılık Türü" açısından erkek çalışanlara nispeten daha yüksek olduğu bulgusuna ulaşmıştır.

Okul yöneticileri ve öğretmenlere göre Kuantum Liderlik davranışları, Yönetim Tarzları ve Öğretmenlerin Örgütsel Bağlılıklarıyla ilişkili midir?

Grupların kuantum liderlik davranışları ve yönetim tarzlarının örgütsel bağlllıkla ilişkisi (ÇBÖ) çok boyutlu ölçekleme analiziyle (PROXSCAL) incelenmiştir. Wickelmaier, (2003) çok boyutlu ölçekleme analizini (ÇBÖ) çok değişkenli ve keşfedici bir veri analizi tekniği olarak ifade eder. ÇBÖ analizinin esas sonucu ortaya çıkan uzaysal haritadır. Ortaya çıkan bu haritada noktalar nesnelerin yerini gösterir. Analiz sürecinde nesneler arasındaki benzerlik ve nesneler arası uzaklıklar karşılaştırılır. Noktalarla gösterilen ve benzer olan nesneler birbirine daha yakın, farklı olan nesnelerse birbirlerine daha uzaktır. Yine bu analizde gerginlik oranı, ÇBÖ çözümlemesi sürecinde karar vermede bir ölçüt olarak kullanılmaktadır. Buna göre düşük gerginlik değeri çözüm için uygunluğu gösterir(Yenidoğan, 2008). Analiz sonuçları iki boyutlu çözümün (S-Stress= .04) değişkenler arası ilişkileri açılamada yeterli olduğunu göstermektedir. Sonuçlar Şekil 2.'de verilmiştir. 


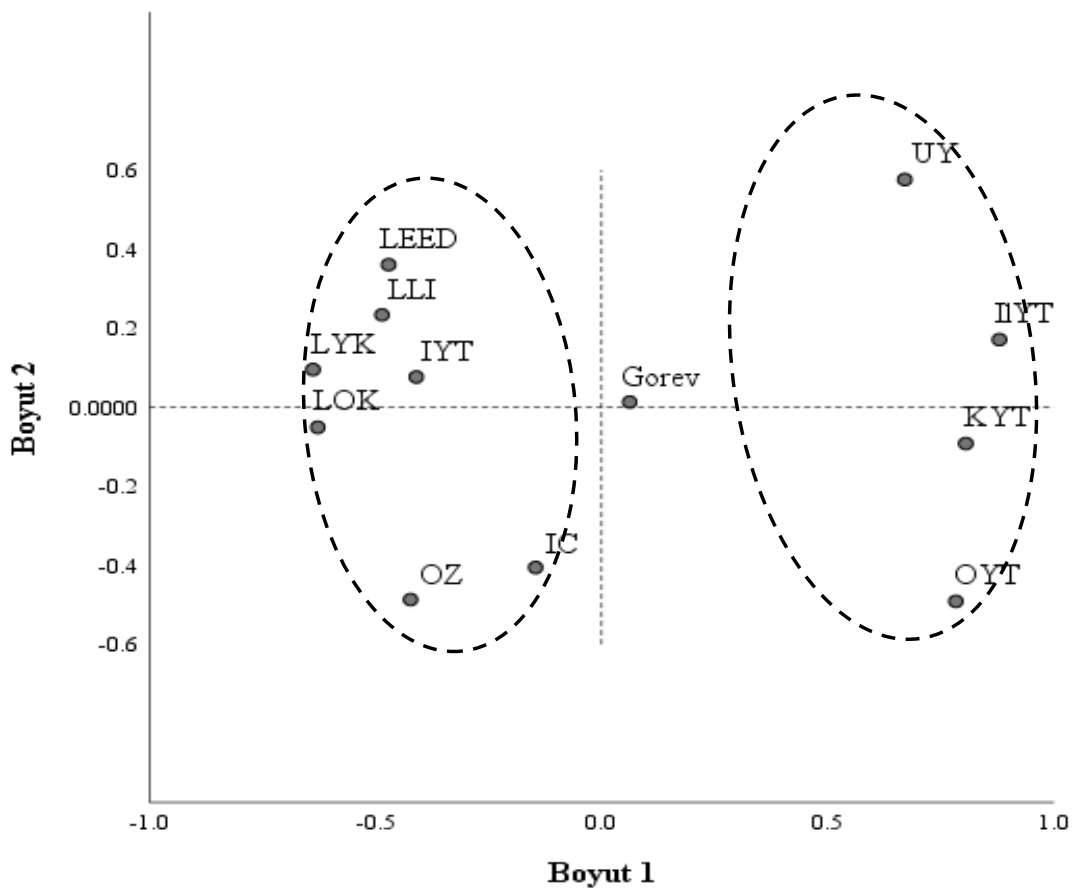

Şekil 2. Türetilmiş Değişken Yapılandırması

Not: LLI: Liderlik, lider-izleyenler ikileminde bir etkileşim alanıdır; LYK: Liderlik yapılandırılamaz ve kestirilemez; LOK: Liderlik olgusunun kesikliliği, LEED: Liderliğin etkisi etkileşime dayalıdır; IYT: İşbirlikli; OYT: Otoriter; IIYT: İlgisiz; KYT: Karşı koyucu; UY: Uyum; OZ: Özdeşleşme; IC: İçselleştirme; Görev (Yönetici=0, Öğretmen=1)

Şekil 2.'de, kuantum liderlik davranışları (LLI, LYK, LOK ve LEED), İşbirlikli yönetim tarzı, özleştirme ve içselleştirme şeklindeki örgütsel bağlılıklar ilişkili görünmektedir. Ayrıca karşı koyucu ve otoriter yönetim tarzları ile Uyum şeklindeki örgütsel bağlılık ilişkilidir. Orijinde yer alan görevin ise bu değişkenlerle ilişkisi düşüktür. Bunu, okullarda yöneticilerin kuantum liderlik davranışı sergilemeleri durumunda; yöneticilerin problem cümlemiz çerçevesinde sergileyecekleri demokratik-işbirlikli yönetim tarzıyla ilişkili olduğu yine örgütsel bağl1lık alt boyutlarından özdeşleştirme ve içselleştirme alt boyutlarıyla ilişkili olduğu sonucuna ulaşılmıştır denilebilir.

Araştırmaya ilişkin alan yazın taramasında, elde edilen bulguları destekler şekilde benzer araştırma sonuçlarının var olduğu, farklı liderlik 
davranışlarının örgütteki süreç veya davranışlarla ilişkili olduğu, bu davranışlar üzerinde olumlu etkilere sahip olduğu ifade edilebilir. Araştırmada son olarak dördüncü alt problem kapsamında konu ele alındığında; ulaşılan bulguların konuya ilişkin alan yazını destekler şekilde okul yöneticilerinin sergiledikleri kuantum liderlik davranışlarının hem okul yöneticilerinin yönetim tarzları hem de öğretmenlerin örgütsel bağlllık düzeyleri ile ilişkili olduğu ve olumlu bir biçimde etkilediğini ortaya koyduğu anlaşılmaktadır. Tersi durumda birlikte değişim ilkesi çerçevesinde Demokratik-İşbirlikli yönetim tarzı ve öğretmenlerin yüksek düzeyde örgütsel bağlllık sergilemelerinin de okullarda görev yapmakta olan okul yöneticilerinin kuantum liderlik davranışlarına olası olumlu etkisinden söz edilebilir.

\section{Demografik bulgular}

Araştırmada verilere kaynaklık eden öğretmenlere ilişkin demografik bilgiler Tablo 9.'da verilmiştir.

Tablo 9. Katılımcılar İlişkin Demografik Bilgiler.

\begin{tabular}{llll}
\hline Cinsiyet & Kadın & 669 & 68,1 \\
Toplam & Erkek & 313 & 31,9 \\
& & 982 & $\% 100$ \\
Okul Türü & Anaokulu & 37 & 3,8 \\
& illokul & 366 & 37,3 \\
& Ortaokul & 305 & 31,0 \\
Toplam & Lise & 274 & 27,9 \\
Okulun & & $\% 82$ & \\
Bulunduğu Ilç̧e & & & 10,9 \\
& Altundă̆ & 107 & 18,3 \\
& Çankaya & 180 & 9,8 \\
& Etimesgut & 96 & 4,4 \\
& Göbaş1 & 43 & 17,2 \\
& Keçören & 169 & 11,8 \\
& Mamak & 115 & 3,5 \\
& Pursaklar & 34 & 10,4 \\
& Sincan & 102 & 13,7 \\
& Yenimahalle & 136 & \\
\hline
\end{tabular}

Araştırmada tablo. 9. 'da görüldüğü üzere 982 öğretmen görüşüne yer verilmiştir.

Tartışma ve Sonuç 
Araştırmada öğretmen görüşlerine göre; okul yöneticilerinin kuantum liderlik davranışı sergileme düzeyinin okul düzeyi değişkenine göre farklılaşıp farklılaşmadığına ilişkin yapılan analizlerde elde edilen sonuçlara göre istatistiksel bakımdan önemli düzeyde farklılık gözlenmemiştir. Ancak Anaokulu ve İlkokulda görev yapan öğretmenlerin kuantum liderliğe ilişkin ifadelere Lise öğretmenlerinden daha yüksek puanlar verdikleri izlenmiştir. Bu sonuca göre, Anaokulunda ve İlkokulda görev yapan öğretmenlerin okul yöneticilerinin kuantum liderlik davranışı sergilemelerine ilişkin Ortaokul veya Lisede görev yapan öğretmenlerden daha olumlu algılara sahip oldukları izlenmiştir.

Araştırmada öğretmen görüşlerine göre okul yöneticilerinin kuantum liderlik davranışı sergileme düzeylerinin cinsiyet değişkenine göre farklılaşıp farklılaşmadığına ilişkin yapılan analizlerde elde edilen sonuçlara göre istatistiksel bakımdan önemli düzeyde farklılık gözlenmemiştir. Yani öğretmenlerin erkek veya kadın olmasının okul yöneticilerinin kuantum liderlik davranışı sergileme düzeylerine ilişkin görüşleri üzerinde anlamlı bir etkisinin olmadığı, cinsiyet değişkeni çerçevesinde tüm öğretmenlerin okul yöneticileri tarafından sergilenen kuantum liderlik davranış düzeyine ilişkin birbirlerine benzer görüşleri paylaştığı sonucu elde edilmiştir.

Araştırmada öğretmen görüşlerine göre okul yöneticilerinin yönetim tarzının okul düzeyi değişkenine göre farklılaşıp farklılaşmadığına ilişkin yapılan analizlerde elde edilen sonuçlara göre istatistiksel bakımdan önemli düzeyde farklılık gözlenmemiştir. Ancak; okul yöneticisinin yönetim tarzına ilişkin okul düzeyi değişkenine göre Anaokulu ve İlkokul öğretmenleri okul yöneticilerine daha yüksek puanlar verdikleri görülmüş̧ür.

Araştırmada öğretmen görüşlerine göre okul yöneticilerinin yönetim tarzının cinsiyet değişkenine göre farklılaşıp farklılaşmadığına ilişkin yapılan analizlerde elde edilen sonuçlara göre istatistiksel bakımdan önemli düzeyde farklılık gözlenmemiştir. Okul yöneticisinin yönetim tarzına ilişkin okul düzeyi değişkenine göre öğretmen görüşlerinin birbirine yakın seyrettiği görülmüştür. Ancak; puan ortalamalarına göre erkek ( $n=313)$ öğretmenlerin, kadın ( $n=669)$ öğretmenlere göre ifadelere katılım durumları kapsamında yöneticilerini daha "otoriter" ve "ilgisiz" 
algıladıkları saptanmıştır. Bu puan farklılı̆̆ının nedeni okul yöneticilerinin kadın çalışanlara karşı nezaketleri olabilir.

Araştırmada öğretmen görüşlerine göre; öğretmenlerin örgütsel bağll1ık düzeyi okul düzeyi değişkenine göre farklılaşıp farklılaşmadığına ilişkin yapılan analizlerde elde edilen sonuçlara göre "Uyum" ve "Özdeşleşme" ölçeklerindeki puan ortalaması farklarının önemli olduğunu, "İçselleştirme" alt boyutuna göre istatistiksel bakımdan anlamlı düzeyde bir farklılık olmadığı saptanmıştır. Burada öğretmen görüşleri çerçevesinde Anaokulu ve İlkokullarda görev yapmakta olan öğretmenlerin okula yönelik örgütsel bağlllık durumlarına ilişkin algıları daha olumlu olarak tespit edilmiştir.

Araştırmada öğretmen görüşlerine göre; öğretmenlerin örgütsel bağlılık düzeyi cinsiyet değişkenine göre farklılaşıp farklılaşmadığına ilişkin yapılan analizlerde elde edilen sonuçlara göre "Uyum" alt boyutunda erkek öğretmenler lehine bir puan farkı görülmesine karşın istatistiksel bakımdan anlamlı düzeyde bir farklılık olmadı̆̆ saptanmıştır.

Araştırmanın dördüncü alt problem cümlesi çerçevesinde "okul yöneticileri ve öğretmenlere göre; okul yöneticilerinin sergilediği Kuantum Liderlik davranışları, Yönetim Tarzları ve Öğretmenlerin Örgütsel Bağlılıklarıyla ilişkili midir?" sorusuna ilişkin yapılan analizlerde elde edilen sonuçlara göre; okullarda yöneticilerin kuantum liderlik davranışı sergilemeleri, okul yöneticilerin sergileyecekleri demokratik-işbirlikli yönetim tarzıyla ilişkili olduğu yine örgütsel bağlılık alt boyutlarından "özdeşleştirme" ve "içselleştirme" alt boyutlarıyla ilişkili olduğu sonucuna ulaşılmıştır.

Bu çalışma, Ankara ili dokuz merkez ilçede yer alan okullarda görev yapmakta olan öğretmenlerin "okul yöneticilerinin kuantum liderlik davranışı sergileme düzeylerinin yönetim tarzlarına ve öğretmenlerin örgütsel bağlllık düzeylerine etkisi nedir?" problem cümlesine dönük algıları çerçevesinde ortaya çıkmıştır. Var olan durumu ortaya koymaya yönelik betimsel bir çalışma olan bu araştırma çerçevesinde okul yöneticilerinin kuantum liderlik davranışlarına dönük algıları okul düzeyi ve cinsiyet değişkenlerine göre farklılaşıp farklılaşmadığı sorgulanmıştır. Çalışmada nicel araştırma yöntemlerinden 
yararlanılmıştır. Araştırma sonucunda aşağıdaki önerilerde bulunulmuştur. Öneri olarak;

\section{Araştırmaya ilişkin;}

1. Okul yöneticilerinin kuantum liderlik davranışı sergilemesine ilişkin Anaokulu, İlkokul, Ortaokul ve Lise düzeyinde görev yapan öğretmenlerin, birbirlerinden farklı görüşlere sahip olmalarının altındaki sebepler araştırılabilir.

2. Okul yöneticilerinin yönetim tarzına ilişkin okul düzeyi değişkeni çerçevesinde oluşan farklılığın sebepleri araştırılabilir.

3. Erkek öğretmenlerin kadın öğretmenlere göre yöneticilerini daha otoriter ve ilgisiz algılamalarının altındaki sebepler araştırılabilir.

4. Örgütsel bağlılıkla ilgili, İlkokullarda ve Liselerde görev yapan öğretmenler ile Ortaokullarda görev yapan öğretmenler arasındaki görüş farklılıklarının nedenleri araştırılabilir.

5. Örgütsel bağlılığa ilişkin kadın ve erkek öğretmenlerin görüşlerindeki farklılığın sebepleri araştırılabilir.

\section{Uygulamaya ilişkin;}

1. Pandemi süreciyle birlikte ihtiyaç duyulan ve daha geniş bir perspektiften ortaya konulabilecek çözüm önerileriyle kaos ve karmaşıklığı bir fırsata dönüştürme becerisi edinmeyi destekleyen kuantum liderliğin, MEB'in yönetici becerilerinin geliştirilmesine yönelik çalışmalarında yer alması yönetim uygulamalarına katkı sağlayabilir.

2. Kuantum liderliğin seminer ve hizmet içi eğitim çalışmalarıyla erkek ve kadın okul yöneticilerine anlatılması yarar sağlayabilir.

3. Kuantum liderliğin, yönetim tarzı ve örgütsel bağlılıkla ilişkisi bu araştırma ile ortaya konmuştur. Okulların gelişimine katkı sağladı̆̆ı görülen örgütsel bağlılık düzeyinin okullardaki öğretmenlerde yükseltilmesi için okul yöneticileri çalışmalar yapabilir.

4. Kuantum bakış açısının sağlayacağı avantajları ve farklı perspektifleri düşünerek İl ve İlçe Yöneticilerinin özellikle yeni göreve başlayan okul yöneticilerine bu kapsamda eğitim çalışmaları önerilebilir. 
EXTENDED ABSTRACT

\title{
Analysis of Quantum Leadership in the Context of Management Styles and Organizational Commitment
}

\author{
Methi Çelik- Şefika Şule Erçetin \\ MONE- Hacettepe University
}

The scientific achievements and developments that emerged with the emergence of Copernicus's "On the Rotations of the Celestial Spheres" in 1543 and the "Mathematical Principles of Natural Philosophy" by Newton in 1687 can be cited as the source of the change and transformation experienced today. In this process called "Science Age", science; It has influenced society, schools, changed people's minds, offered new perspectives to social theorists, people; By changing its attitude towards habits and traditions, it paved the way for living independent from the past (Alatll, 2010, p.770). Since Newton's views, which influenced humanity's perception of the universe for approximately 250 years, evaluated the world in a precise and predictable way, this period's scientists studied the laws of nature mechanically and mathematically. Quantum Theory, have opened a new horizon to our perception of science all over the world, with a different perception from Newtonian physics(Servay, 1996, Erçetin, 2000, Zohar, 2019, Brooks, 2010, Crease \& Goldhaber, 2016).

Quantum leadership, whose basic assumptions are "an area of interaction between the leader and his followers unconfigurable and unpredictability, intermittency-discontinuity, commitment to interaction" (Erçetin, 2000), is considered to be a type of leadership that is expected to be displayed by the administrators who have the management under their responsibility. When considering any school in our country and the world, it can be seen in various research results that the educational administrators working here reveal different leadership types and management styles (Ustuner, 2016). School administrators who have absorbed the principles of quantum leadership, which is one of these types of leaderships, and reflected it on their behaviours, is in 
constant interaction with employees. They support interaction with all communication channels and do not discriminate between employees. They know themselves as a member and part of the organization called the school and do not see themselves above the employees. By identifying the needs of the employees, they find ways to meet them and integrate with the employees. They stay away from dominating or judging attitudes and behaviours over employees. On the contrary, they guide and give consultation to the employees. Because they know that the strength of the school is in the common power and synergy created by all employees. They ensure the adoption of a common vision by sharing power with employees. As a result of informal interactions; mutual motivation, openness, transparency, honesty, trust, respect for roles/persons, maintaining the learning and development are at the forefront (Ercetin, 1999, Ercetin and Kayman, 2014, Kosa, 2020).

Another important pillar of our research is the concept of management style. Different from leadership, the management style, which is defined as the ability to gather certain people together in line with the determined goals and to mobilize the group to realize them (Eren, 2008a, p.431), is considered, in the simplest terms, as the route that managers follow to achieve success (Rees \& Porter, 2008).

The third pillar of our research is the concept of organizational commitment. Defined as the desire of the employees in the organization to stay and serve faithfully, the commitment to the goals and values of the organization and the attitude and feelings to create an environment for the realization of these goals, and for employees to sacrifice and to devote themselves to the organization (Aslan \& Bakır, 2014, p.192), organizational commitment is an important condition for schools. The concept of organizational commitment can be expressed as the organization in which the employees take part, claiming the goals determined by the policy, fulfilling the requirements of their duties, keeping the interests of the organization above their personal interests, performing selflessly, devoting more time to the organization when necessary, and bonding with moral ties rather than material ties (Balay, 2000).

In the light of these explanations, school administrators who have internalized quantum leadership behaviour can be expected to display a 
democratic-cooperative management style in the functioning of the school's work and operations. On the other hand, it can be predicted that school administrators who have internalized quantum leadership behavior will contribute positively to the school's commitment to the employees as a result of the positive attitude and behavior that the school will exhibit towards its employees.

In this study, it was aimed to determine the level of the relationship between them by revealing whether the levels of quantum leadership behavior, management styles, and organizational commitment levels of teachers who work in schools within the sample differ according to some variables.

\section{Kaynakça/References}

Açıkalın, A. (1994). Teknik ve toplumsal yönleriyle okul yöneticiliği. Ankara: Pegem Yayınları.

Akçay Güngör, A.(2018). Etkili okul özelliklerinin dönüşümsel liderlik ve öğretmen bağhllığıyla ilişkisi. Yayınlanmamış doktora tezi. Ege Üniversitesi, İzmir Alatlı, A. (2010). Batıya yön veren metinler.(4 Cilt). İlke Eğitim ve Sağlık Vakfı. Kapadokya MYO. İstanbul: Melisa Matbaacılık.

Aslan, M. ve Bakır, A. A. (2014). Öğretmenlerin okullarındaki örgütsel bağllliğa ilişkin görüşleri. The Journal of Academic Social Science Studies,International Journal of Social Science, 25, 189-206. doi:org/10.9761/JASSS2249.

Balay, R. (2000). Yönetici ve öğretmenlerde örgütsel bağlllk. Ankara: Nobel Yayın Dağıtım.

Bass, B. M. (1990). Bass \& Stogdill 's Handbook of leadership: Theory, research, and managerial application. (3rd ed.). New York: Free Press.

Başaran, İ. E. (2004). Yönetimde insan ilişkileri. Ankara: Nobel Yayın Dağıtım.

Brooks, M. (2010). Büyük sorular. Zamanda seyahat edebilir miyiz? (The Big Questions / Physics). (E. Kılıç, Çev.). İstanbul: Versus Kitap.

Büyüköztürk, Ş. (2007). Sosyal bilimler için veri analizi el kitabı. (8. b.). Ankara: PegemA Yayıncilik.

Crease, R.P. ve Goldhaber, A.S. (2016). Kuantum dönemi. Planck, Bohr, Einstein ve Heisenberg belirsizliği sevmeyi bize nasıl öğretti? (V. Arı, Çev.). İstanbul: Bilgi Üniversitesi Yayınları. 
Erçetin, Ş. Ş. (1999). Kuantum liderlik paradigması ile eğitim liderliğinin açımlanması. MEB Cumhuriyet Döneminde Ĕ̆itim II. Ankara: Milli Eğitim Basımevi.

Erçetin, Ş. Ş. (2000). Lider sarmalında vizyon (2. b.). Ankara: Nobel Yayın Dağıtım.

Erçetin, Ş.Ş., Çevik, M.S. ve Çelik, M.(2018). Okul müdürlerinin kuantum liderlik davranışlarını gerçekleştirme düzeyleri. Uluslararası Liderlik Çalışmaları Dergisi, 1(2), 109-124.

Erçetin, Ş,Ş. ve Kayman, E.A. (2014) How to be a quantum leader in an intelligent organization? Ş.Ş. Erçetin \& S.Banerjee (Eds.) Chaos, Complexity and Leadership. New York: Springer International Publishing.

Erçetin, Ş. Ş., Potas, N., Açıkalın Ş. N. ve Turan, S. (2017). A study for developing a viable quantum leadership scale. International Congress On Political, Economic and Social Studies Abstracts Book. (9-11 November, 2017), Ankara.

Eren, E. (2008). Örgütsel davranış ve yönetim psikolojisi (11 b.). İstanbul: Beta.

Hodgkinson, C. (2008). Yönetim felsefesi, örgütsel yaşamda değerler ve motivasyon (1 b.). Çev. İ. Anıl, ve B. Doğan. İstanbul: Beta.

İşeri, B. (2019). Okul müdürlerinin yönetim tarzına ilişkin öğretmen görüşleri. Yayınlanmamış yüksek lisans tezi. Abant İzzet Baysal Üniversitesi, Bolu.

Kahraman, Ü. (2019). Okul yöneticilerinin yönetim tarzl, örgüt dna'st ve örgütsel değişimin okullardaki korku kültürüne etkisi. Yayınlanmamıs doktora tezi. Pamukkale Üniversitesi. Denizli.

Karasar, N. (2008). Bilimsel araştırma yöntemi, kavramlar-ilkeler-teknikler. (18.Baskı) Ankara: Nobel Yayın Dağıtım.

Kosa, G. (2020). Yöneticilerin kuantum liderlik algılarının incelenmesi üzerine nitel bir araştırma. MANAS Sosyal Araştırmalar Dergisi, 9(2) , 916-926.

Olgungül, F. K. (2017). Örgütsel bağhlllk ve çalş̧ma süresi ilişkisi üzerine bir araştırma: Devlet ve özel ortaögretim okullarında görev yapan öğretmenler örneği. Yayınlanmamış doktora tezi. Gazi Üniversitesi, Sosyal Bilimler Enstitüsü. Ankara.

Özdemir, A. N. (2020). Okul yöneticilerinin çevik liderlik özelliklerinin örgütsel bağhlliğa etkisi: Inngiltere ve Türkiye okullarında karşılaştırmah bir analiz. Yayınlanmamış doktora tezi. Marmara Üniversitesi. İstanbul.

Rees, D.W. ve Porter, C. (2008). Skills of management. 6. Bask1, London: Cengage 
Servay, R.A. (1996). Fen ve mühendislik için fizik. 3. modern fizik. Çev. Ed. Kemal Çolakoğlu. Ankara: Palme Yayıncılık.

Şat, A. (2018). Çalışanlarda örgütsel pasif-agresif davranışların yordayıcısı olarak yönetim tarzları algısı, örgütsel adalet algısı ve kişilik. Yayımlanmamış doktora tezi. Erciyes Üniversitesi, Sosyal Bilimleri Enstitüsü, Kayseri.

Tufan, M. (2019). Okul yöneticilerinin kuantum liderlik davranışları ile öğretmenlerin inisiyatif alma düzeyleri arasındaki ilişki. (Kartal İlçesi Örneği). Yayınlanmamış yüksek lisans tezi. Yıldız Teknik Üniversitesi, Sosyal Bilimler Enstitüsü, İstanbul.

Turan, S. (2017). Okul yöneticilerinin kuantum liderlik davranışlarının örgütsel zekâ düzeyine etkisi. (Zonguldak ili örneği). Yayımlanmamış doktora tezi. Hacettepe Üniversitesi, Eğitim Bilimleri Enstitüsü, Ankara.

Üstüner, M. (2016). Algılanan müdür yönetim tarzı ölçeğinin geçerlik ve güvenirlik çalışması. Kuram ve Uygulamada Ĕ̆itim Yönetimi, 22(3), 429457.

Yağ, T. (2019). Okul yöneticilerinin yönetim tarzlarn ile hesap verebilirlik yönelimleri arasındaki ilişki. Yayınlanmamış yüksek lisans tezi. Kırşehir Ahi Evran Üniversitesi, Sosyal Bilimler Enstitüsü, Kırşehir.

Yenidoğan, T. G. (2008). Pazarlama araştırmalarında çok boyutlu ölçekleme analizi: üniversite öğrencilerinin marka algısı üzerine bir araştırma, Akdeniz İ.I.B.F. Dergisi, 15, 138-169.

Zohar, D. (2019). Kuantum benlik. (2. Basım). Çev. S. Kervanoğlu. İstanbul: Ayrintı Yayınları.

\section{Kaynakça Bilgisi / Citation Information}

Çelik, M. ve Erçetin, Ş. Ş. (2021). Kuantum liderliğin, yönetim tarzları ve örgütsel bağlılık bağlamında analizi. OPUS- Uluslararası Toplum Araştırmaları Dergisi, 18(43), 6868-6896. DOI: 10.26466/opus.938653. 